\title{
Preparing Engineering Students for the Communication Exigencies of the Profession: Exploring the Future of Technical Communication in Engineering Education
}

\author{
Anne Parker, Ph.D. \\ Associate Professor and Technical Communication Coordinator \\ Design Engineering, University of Manitoba \\ Anne_Parker@umanitoba.ca
}

\begin{abstract}
This paper will explore a timely and critical question in engineering education: is there a "best" way to help our engineering students develop the "communicative competence"[1] they will need in the highly demanding world of the professional engineer? I will argue that, similar to engineering design, there is no single, perfectly elegant solution; rather, there may be combinations and permutations that lead to a "best" answer. I will nonetheless attempt to answer the question. To do so, I will mention what other schools do in their programs (at least the ones that I know of). My focus, however, will be the University of Manitoba and how we have attempted to solve this conundrum. I will conclude the exploration by looking at some of our recent initiatives that may spotlight some of the future directions that communication may take in engineering education.
\end{abstract}

\subsection{Introduction}

In the past, Engineering schools have tried to find the "best" way of making our students communicatively competent; various ways have been tried, including parachuting instructors from English departments into the classroom and, more recently, adopting alternatives like WAC ("Writing Across the Curriculum) and WID ("Writing in the Disciplines"). Such approaches certainly have a place within the academy. However, are these the most efficacious methods by which to help our engineering students become more communicatively competent? And here is the conundrum we face: if we acknowledge that the technical communication course should be an integral part of the engineering curriculum, as the accreditation board expects us to do, should it be a course that mirrors a traditional course in rhetoric and composition - and one taught by an instructor from outside the Engineering discipline? Is this scenario the "best" way to do that? If not, then who should teach such a course? Does that mean its instructor needs to be an expert in the study of the English language, such as an EAL instructor would be? Or should this person be an engineer? Or some combination of both? To complicate things even further, one last question might be what topics should be included. In other words, what do our students need to know?

In the following paper, I will attempt to explore these questions by, first, exploring some of these scenarios. Along the way, I will look at what some schools do in their communications courses as well as what we do at the University of Manitoba, which I obviously know best. Finally, I will attempt to answer the questions raised by outlining yet another scenario; that is, some of the initiatives that we are hoping to implement into the program at my university.

\subsection{Scenario One: The Transplanted "English" Teacher}

Many years ago, when the technical communication course was first being introduced, many Engineering schools sought help from English departments, ostensibly the place to go for help with writing. In fact, in 1978, our faculty at the $\mathrm{U}$ of $\mathrm{M}$ did the same thing. At a time, however, when being assigned to teach a course in composition was often interpreted as a demotion, most professors and even graduate students in the department considered teaching this new course of "technical writing" to be worse than a demotion; it was a punishment. No one even knew what such a course was truly about, and so most of the instruction followed the usual composition model: basic grammar 
instruction; grammar exercises; readings and discussions; instruction in the various forms of persuasion; and so on. Some of the early texts followed a similar pattern, although they also introduced the genres of engineering writing, like the different kinds of reports, and usually students had at least a technical subject of some sort to write about (though one of the first instructors that I knew had her engineering students write a set of instructions, in this case, a recipe for Yorkshire pudding).

Nevertheless, this view of English departments as somehow possessing the expertise required for such a course still persists. Two fairly recent examples will suffice, one from the University of Western Ontario, which a few years ago opted to call on the resources of their English department to teach communication to some $400+$ students a year; later, the writing resource centre took on the task. The other is York University, which at the time was preparing to apply for accreditation; they also thought the English department could teach the technical communication requirement and would satisfy the accreditation criterion.

However, in their seminal articles, Mathes, Stevenson and Klaver argued some 30 years ago that the English department was emphatically not the "best" way to help our students develop communicative competence. For one thing, English professors were (and still are, as far as I know) trained to analyze literature; learning how to write and speak about engineering work would seem to be out of that domain. Mathes, Stevenson and Klaver went on to argue that, "because of its concern with unambiguous, rational statement," technical communication demanded that students match the practical subject with a practical style: clear, unambiguous, objective [2, p. 4] [3]. One could argue - and many did, and in particularly prestigious journals [4] - that the study of English literature is equally rational and objective. However, there is also the question of emphasis.

On the one hand, technical writing had what Mathes, Stevenson and Klaver called an "important societal function" [2, p. 6]. On the other hand, it also had to attend, above all else, to what Gale called "the needs and desires of its intended audience" [5, 141] usually a client who was paying for the privilege of reading the document. Because of this very different emphasis, technical communication had to become an advanced Engineering course where producing the communications in the course had to be regarded as a "technical activity" rather than as an "extension of English composition" (2, endnote 11,p. 17).

\subsection{Scenario Two: The Communication Course as a Cornerstone}

Thus, according to Mathes, Stevenson and Klaver, instead of becoming an extension of the English department or a composition course, technical communication should not be a "foundation course" akin to the usual first-year courses [2, p. 12]. Notwithstanding their very emphatic and convincing arguments, however, even today some courses in professional or technical communication are perceived as "foundational," and even advertised as such; at the University of Saskatchewan, for example, the required course for students in Engineering and Agriculture (RCM 300.3 "Effective Professional Communication") is called a "foundational course" [6].

But is calling it "foundational" necessarily a bad thing? Indeed, I have argued (at the 2008 CDEN conference in Halifax) that the stand-alone course we offer at the University of Manitoba is a "cornerstone" in our Engineering curriculum, primarily because it offers ample time and practice in communication and teaming. So, unlike the WAC or WID approach, where communication is incorporated into an existing technical course, the technical communication course at the University of Manitoba becomes the "foundation" upon which subsequent courses can build, like the senior design (or capstone) project.

So, "foundational" should not be seen as a pejorative term. A cornerstone implies that it is an important part of a structure, a part that cannot be removed without compromising the entire structure. This is certainly a quaint metaphor, but is it an appropriate one? I would say that it is. Simply put, engineers solve problems, but they also must communicate solutions [7, p. 107] [8, p. 13b5-1]. To do so, they need to possess the requisite communication skills, something a communications course can certainly give them.

Taking this further, in their earlier paper, Mathes, Stevenson and Klaver make the astonishing claim that an engineer typically spends more time writing than does the liberal arts graduate [2, pp. 1-2]. In that case, our engineering students need even more opportunities 
to develop the communication skills they will need as professionals and, according to Mathes, Sevenson and Klaver [2], who better to teach them than the professor with the P.Eng.?

They argue that engineering professors should be responsible for technical communication (they are careful to say that technical writing instructors should also be hired, but the logistics of the arrangement are left deliberately vague; this is a topic I'll come back to later when I consider partnerships). The reasons for having engineering professors involved are fairly straightforward. For one thing, they bring knowledge of the professional context in which students will have to function after they graduate; engineering professors can then apply technical communication principles to the simulated or industry-based projects that students work on. For another thing, how engineers design their projects is comparable to how they will design their communications. This is the kind of "situated learning" [9] that will help our students to learn "disciplinespecific communication" [10].

Finally, according to Reave, a "well-designed" program begins with a "good foundation" that a standalone course in technical communication can provide. She concludes that such a program, directed by communication specialists who work full-time to develop it, needs to "provide high-quality instruction," direction and feedback "for the communication tasks of the profession" [11, p.482]. To do that, engineering schools need to commit to further instruction throughout the curriculum, such that other courses integrate communication into the class and students can indeed build on their communication skills within a technical and a professional context.

\subsection{Scenario Three: Creating a Partnership - the synergy between engineering and communication design}

The WID and WAC alternatives are two of the more recent alternatives that Engineering schools have tried. At the $\mathrm{U}$ of $\mathrm{T}$, communication is integrated into existing technical courses, and the instructors help students prepare the documents required by the course both by offering classes and coaching. The $\mathrm{U}$ of $\mathrm{M}$ has also adopted this strategy in our capstone courses; specifically, the MECH 4860 in Mechanical
Engineering and ECE 4600 in Electrical and Computer Engineering. Since design itself is a "communicationintensive activity" [7. p. 105], students need to have the time available to consult with the communication specialists and to work on their reports and presentations. Similarly, a focus on design will enhance the communication since all reports and presentations are "rhetorically and graphically designed to accomplish specific purposes for specific audiences" [7, p. 105]. As a team-taught course, our presence in the classroom facilitates those outcomes.

However, the danger here is that the course will not underline this kind of synergy. Students are working on projects that are seeking solutions to real-life, industrybased problems. As such, students may tend to see the technical work as more important; it is the "real work, and so students will spend too little time on developing and practicing the necessary communication tasks [12, p. 80]. Yet, even if they do spend the time, they may narrowly focus only on the "texts and genres produced [only] in that particular project" $[12$, p. 68). As Paretti cautions, students must still present their design in written, graphical and oral form, and these function as far more than just "vehicles for grades" [13, p. 493]. These documents go to both the client and the instructors, just as their presentations are given to industry partners as well as the academic team. For this important reason, then, students need to know how to shape their documents and oral presentations in ways that will "best support the engineering work" and will therefore help in the exchange of the "necessary information" [13, p. 493]. And they must learn how to do that both in the classroom and in the workplace [11] [14].

How students transfer what they learn in the classroom to what they are being asked to do in the workplace remains problematic, since every graduating student will have a different skill set and each employer will have their own way of doing things. Few technical communication researchers have developed longitudinal studies that follow students from the communications course to the workplace; Artemeva remains one of the few, so this is a murky area. Nevertheless, communication courses can still give students workable strategies that may help them in that transition.

In the stand-alone technical communication class at the University of Manitoba, for example, we include a 
series of strategies for students to use, including a problem-solving strategy [15] [16] that demonstrates the "necessary convergence" [12, p. 325] between engineering and communication. Each will follow the same series of steps from information-gathering to conceptualizing a solution and ending with a product. Both of these processes also demand several iterations because the goal is always satisfying the needs of the client or the user. If students know they possess even a rudimentary skill set and know how to analyze their target audience, then the transition from the academy to the workplace may be that much easier.

The capstone courses also play an important part. At the University of Manitoba, we have introduced intensive coaching sessions that help students to shape their work and then revise it so that their communications focus on the purpose and on the reader. Some of our other initiatives are outlined below.

\subsection{Some Final Thoughts and Some Future Directions}

What this means is that engineering schools should spend the time considering the "best" way to proceed. Here are some of the initiatives - or "best" ways - that the Faculty of Engineering at the University of Manitoba is hoping to implement within the next year or two.

Developing an individual portfolio is an example of one such initiative. Students in the technical communication class compile the drafts they've worked on in two revision tutorials (in which they learn how to analyze their writing and then revise it). In the first tutorial, one of their colleagues from their own team reviews the drafts; the colleague then responds in writing and in a one-on-one conference. The writers must then decide which suggestions they will incorporate - and why. In the second tutorial, two teams exchange drafts and respond to them. Once again, the writers must decide what to change. Students include these drafts, along with any others they feel should be included, and write a short summary of the writing and revising process. So far, this has been one of the more successful assignments (at least if their summaries are to be believed). We are hoping to expand the portfolio to include their later projects as well [17].
Another initiative is the creation of a textbook. Based on my currently published text, which is the one we now use, this new textbook will be the result of intensive consultations between the communication specialists and the capstone coordinators. We are hoping that an innovative group formed by our dean and his staff - affectionately called "Friends of Engineering" - will help to fund this project. We are also considering having students participate in the textbook's preparation, something a colleague at Carleton has done quite successfully [18].

Finally, this same group, we hope, will help us to form an advisory committee, comprised of engineering faculty, communication specialists and industry partners. This is a model that we believe will help the communications program at the University of Manitoba become even "better" at what it does. By helping us understand the communication exigencies in the profession, this advisory group can guide us and help us to tailor our course material to those areas that they identify as important to the profession. In this way, all our stakeholders will benefit.

Of course, "good writing [may well be] good writing in any discipline" [11, p. 468]. But it is important to note that our students still have to learn how to be good writers, on one level, and successful writers, on another. That is, our students need to learn what makes their writing very good or merely "adequate" in an engineering context. They then need to learn how to improve it so they can craft memos, proposals or final reports that will help them succeed in the profession. As Reave states: "Although general principles of good writing transcend disciplinary boundaries, different disciplines also create writing genres that have specific rhetorical demands" [11, p. 468] - demands that every student needs to master if they are going to be successful at what they do. Simply put, requiring students to write reports and orally present their work is one thing, but helping them to improve it is quite another. And for that, engineering schools should consider the types of partnerships outlined here.

However, creating a partnership should not, as Reave warns, simply translate into a misguided belief that anyone can teach technical communication $[11, \mathrm{p}$. 470]. Rather, a partnership should suggest that all the stakeholders recognize the inherent similarity between engineering design and communication design. Equally 
important is the recognition that the practitioners in each area have their own expertise to offer. So, the communication instructors should be communication specialists who have some demonstrated expertise in engineering communication; they should not be transplanted "English" or composition teachers or, more damagingly, people who may simply know how to write well. Too often, the result is a prescriptive approach to communication and not an approach that encourages iterations and coaching and practice within a professional context. More and more, this is becoming a specialty within the larger field of "technical" or "professional" communication, and the engineering classroom should reflect that trend.

In conclusion, I believe there are many "best" ways that we can use to achieve our goals. First and foremost, however, we need a solid base from which to build. Above all, we don't want to create the wacky structures Swift spoke of in Gulliver's Travels, where one of the silly "projectors" at the grand Academy of Lagado truly believed he could build anything from the top down [19]. Engineers and communication specialists both know that we need to build from the ground up. Together, we can design and build a structure that will truly move engineering education forward.

\subsection{References}

[1] M. Bogdanowicz, "Communicative Competence: Business Savvy and the Technical Writer," Technostyle, v.6, no.1, 1987, pp. 1-5.

[2] J.C. Mathes, D.W. Stevenson and P. Klaver, "Technical Communication: The Engineering Educator's Responsibility," Event Number 4350, Paper Presented at the Annual Meeting of the American Society for Engineering Education 1975, 19 p.

[3] J.C. Mathes, D.W. Stevenson and P. Klaver, "Technical Writing: The Engineering Educator's Responsibility," Engineering Education, v.69, no.4, 1979, pp. 331-334.

[4] K.N. Hull, "Notes from the Besieged, or Why English Teachers Should Teach Technical Writing," College English, v.41, no.8, 1980, pp. 876-883.

[5] F.G. Gale, "From the Guest Editor," Journal of Business and Technical Communication, v.10, n.2, 1996, pp. 141-142.

[6] University of Saskatchewan, Effective Professional Communication [Online]. Retrieved May 12, 2010 from http://grahamcentre.usask.ca/Academic programs/RCM300.

$\underline{\mathrm{html}}$

[7] B. Shwom and P. Hirsch, "Re-envisioning the Writing Requirement: An Interdisciplinary Approach," Business Communication Quarterly, v.62, no.1, 1999, pp. 104-107.
[8] D. Ramey aand J. Hudgins, "The Evolution of Integrating Writing into Engineering: Tracing Iterations of Writing Instruction in a Sophomore Engineering Course," in Proceedings, Frontiers in Education Conference, v.3, 1999, pp. 12b5-1-12b5-5.

[9] A. Freedman and C. Adam, "Learning to Write Professionally: 'Situated Learning' and the Transition from University to Professional Discourse," Journal of Business and Technical Communication, v.10, no.4, 1996, pp. 395427.

[10] N. Artemeva, S. Logie and J. St-Martin, "From Page to Stage: How Theories of Genre and Situated Learning Help Introduce Engineering Students to Discipline-Specific Communication," Technical Communication Quarterly, v.8, no.3, 1999, pp. 301-316.

[11] L. Reave, "Technical Communication Instruction in Engineering Schools: A Survey of Top-Ranked U.S. and Canadian Programs," Journal of Business and Technical Communication, v.18, no.4, 2004, pp. 452-490.

[12] J.D. Ford and L.A. Riley, "Integrating Communication and Engineering Education: A Look at Curricula, Courses, and Support Systems," Journal of Engineering Education, October 2003, pp. 325-328.

[13] M.C. Paretti, "Teaching Communicaton in Capstone Design: The Role of the Instructor in Situated Learning," Journal of Engineering Education, v.97, no.4, 2008, pp. 491503.

[14] P. Sageev and C.J. Romanowski, "A Message from Recent Engineering Graduates in the Marketplace: Results of a Survey on Technical Communication Skills," Journal of Engineering Education, 90, pp. 685-697.

[15] A. Parker, "Problem Solving Applied to Technical Writing," The Technical Writing Teacher, v.17, no.2, 1990, pp. 95-103.

[16] A. Parker, Chapter 11, "Introducing a Technical Communication Course into a Canadian School of Engineering," in Design Discourse: Composing and Revising Programs in Professional and Technical Writing. Eds. D. Franke, A. Reid and A. Di Renzo, pp. 203-218, Fort Collins: Colorado: The WAC Clearinghouse and Parlor Press, 2010. Available at http://wac.colostate.edu/books/designdiscourse/

[17] J.M. Williams, "he Engineering Portfolio: Communication, Reflection, and Student Learning Outcomes Assessment," International Journal of Engineering, v.18, no.2, pp. 199-207, 2002.

[18] G. Smart and N. Brown, "Developing a 'Discursive Gaze': Participatory Action Research with Student Interns Encountering New Genres in the Activity of the Workplace," in Rhetorical genre Studies and Beyond, Winnipeg, Manitoba, Inkshed Publications, Eds. N. Artemeva and A. Freedman, 2006.

[19] J. Swift, Gulliver's Travels and Other Writings, Boston, Houghton Mifflin Company, 1960, p. 146. 